\title{
VERBAL COMMUNICATION OF SCHIZOPHRENIC PATIENTS DUE TO NEUROTRANSMITTER DISTORTION
}

\author{
Iskandarsyah Siregar ${ }^{1}$ \\ ${ }^{1}$ Universitas Nasional, Jakarta \\ *Corresponding Address: regaranggi@ presidency.com
}

Naskah diterima: 1 September 2021| Disetujui: 9 September 2021 | Diterbitkan: 30 September 2021

\begin{abstract}
This study aims to analyze the verbal communication of adult schizophrenics who develop due to neurotransmitter distortion. Symptoms of this disease consist of thought processes and disharmony, including such as divisions and rifts, between thought processes, emotions and volitional and psychomotor effects accompanied by distortions of reality, mainly due to delusions and hallucinations. The qualitative descriptive method of a case study is used as a method of analysis by making psycholinguistic studies a foundation. Analysis of understanding of the meaning used in this research is to use pragmatic theory with the principle of cooperation (Grice's theory). Based on the analysis results obtained conversation data that verbals follow the principle of cooperation. Schizophrenic objects are able to respond and organize the stages of language production such as conceptualization, formulation, articulation, and self-monitoring, although they are not consistent. In the process of receptive ability, namely listening, the informant responded with considerable difficulty due to unstable grasping power and concentration on the informant's psyche.
\end{abstract}

Keywords: verbal communication, schizophrenia, patient speech, neurotransmitter distortion

Abstrak: Penelitian ini bertujuan untuk menganalisis komunikasi verbal penderita skizofrenia dewasa yang berkembang akibat distorsi neurotransmitter. Gejala penyakit ini terdiri dari proses berpikir dan ketidakharmonisan, termasuk seperti perpecahan dan perpecahan, antara proses berpikir, emosi, efek kehendak, dan psikomotor disertai dengan distorsi realitas, terutama karena delusi dan halusinasi. Metode deskriptif kualitatif studi kasus digunakan sebagai metode analisis dengan menjadikan studi psikolinguistik sebagai landasan. Analisis pemahaman makna yang digunakan dalam penelitian ini adalah dengan menggunakan teori pragmatis dengan prinsip kerjasama (Grice's theory). Berdasarkan hasil analisis diperoleh data percakapan bahwa verbal mengikuti prinsip kerjasama. Objek skizofrenia mampu merespon dan mengatur tahapan produksi bahasa seperti konseptualisasi, formulasi, artikulasi, dan pemantauan diri, meskipun tidak konsisten. Dalam proses kemampuan reseptif yaitu menyimak, informan merespon dengan kesulitan yang cukup besar karena daya tangkap yang tidak stabil dan konsentrasi pada psikis informan.

Kata kunci: komunikasi verbal, skizofrenia, bicara pasien, distorsi neurotransmitter 


\section{INTRODUCTION}

Language is a tool to convey messages. With this perspective, language success can be measured by the effectiveness and efficiency of conveying the right message from the articulator to the auditor. Attention to the language process is often not enough and is considered less important, even though disputes and conflicts almost always occur due to the creation of conditions of language disagreement or what is often called miscommunication. Conditions of disagreement or miscommunication can occur due to psychological or physical factors. Although, as in the phenomenological perspective, every event occurs with two orientations, intentional or natural.

Schizophrenia comes from two words "Schizo" which means cracked or broken (split), and "phrenia" which means soul. Thus, someone who suffers from a schizophrenic mental disorder is one who experiences a splitting of personality. Schizophrenia can also be defined as a severe mental disorder in the form of loss of contact with reality and difficulty distinguishing what is real from what is not. (Yuliana, 2013). Researchers formulate Schizophrenia as a disorder in the mental system of an organism.

Symptoms of this disease consist of thought processes and disharmony, including such as divisions and rifts, between thought processes, emotions and volitional and psychomotor effects accompanied by distortions of reality, mainly due to delusions and hallucinations (Maramis 1980). This Schizophrenic sufferer has a world of his own), so that other people in communication find it difficult to understand what is being said. Sometimes, these sufferers can spend hours in silence until they begin to explain what they are really thinking. These sufferers also experience language production or psycholinguistic disabilities.

Thinking disorders of people with schizophrenia can be treated biomedically by doctors by giving antipsychotic drugs, psychosocial treatment by psychologists, and therapeutics by nurses as well as support from people who live around sufferers, especially families. The language deficit of people with schizophrenia can recover along with medication, psychosocial treatment, therapeutics from medical experts and support from families.

According to WHO, currently in the world there are more than 450 million people living with mental disorders, in Lewis's study the prevalence rate of schizophrenia mental disorders in the world ranges from 4 per mile, then increased to 5.3 per mile. Whereas in Indonesia in 2007 the prevalence of schizophrenia in Indonesia was 2 per mile then according to WHO the prevalence of schizophrenia in Indonesia in 2013 increased to 2.6 per mile in 2013. Among people with schizophrenia worldwide about $20-50 \%$ have attempted suicide and $10 \%$ of them died by suicide. The mortality rate of people with schizophrenia is 8 times higher than the death rate of the population in general (Hawari, 2012). 
In Indonesia, there are $0.3-1 \%$ of Schizophrenia sufferers and usually appear at the age of 18 - 45 years, but there are also those who are only 11 - 12 years old already suffering from Schizophrenia. If the population of Indonesia is around 200 million people, it is estimated that around 2 million people suffer from schizophrenia.

Schizophrenia occurs for several reasons, one of which is neurotransmitter distortion. A neurotransmitter is a compound that nerve cells use to communicate with each other. Generally, each neuron will synthesize, store and release one type of neurotransmitter, but certain neurons can release more than one neurotransmitter, this is called a cotransmitter (Ikawati, 2014). The most common excitatory neurotransmitter in the CNS is glutamate, while the most common inhibitory neurotransmitter is GABA. The inhibitory neurotransmitter in the spinal cord is glycine. Acetylcholine and norepinephrine are the most important neurotransmitters in the autonomic nervous system but are also found in the CNS. Other important neurotransmitters include dopamine, serotonin, and various types of neuropeptides.

Scientists think that an imbalance in the interrelated chemical reactions in the brain complex involving the neurotransmitters dopamine and glutamate may act as a stimulant for schizophrenia. This condition causes the small pathways in the brain of people with schizophrenia to look different than normal people. For example, the fluid-filled cavities in the center of the brain, called the ventricles, are larger in some people with schizophrenia. The brains of people with schizophrenia also tend to be less gray in areas that should be gray (grey matter) and some areas of the brain have less or more activity than normal people.

\section{METHODS}

Conversational implicature in verbal communication of schizophrenic patients is the object of study in this study. The term implicature is used by Grice to explain what the speaker might mean, suggest, or mean, which is different from what the speaker actually said (Brown and Yule, 1996). Conversational implicature is a deviation from the semantic content of a sentence. The frequency and percentage of illocutionary speech acts in Schizophrenia sufferers were also recorded in this study as a medium for measuring the level of verbal communication in Schizophrenic patients due to distortion of Neurotransmitters (Levinson, 1983).

Case study strategies within the framework of qualitative descriptive research methods are also used in this study. Case studies are defined as methods or strategies in research to uncover certain cases. Case studies of research strategies in the social sciences that investigate phenomena in real-life contexts. A case study is a descriptive analytical activity by applying an in-depth investigation of an 
individual, group, situation, system or event to explore the underlying causes of the principles. Case study research can be single or multiple case studies, including quantitative evidence, depending on multiple sources of evidence and the merits of developing prior theoretical propositions. The orientation of the case study is to develop in-depth knowledge of the object under study, which means that this study is an exploratory study. This research is in-depth so as to produce a description of certain events.

For the record, this study was conducted on Schizophrenia sufferers who were treated intensively at home by the family and nurses who stayed at the house. This treatment strategy is considered more effective by considering a familiar environment that will bring comfort to the patient and speed up the healing process.

\section{RESULTS AND DISCUSSION}

\section{Maxim of Quantity}

The maxim of quantity requires each participant of the speech to contribute as soon as possible or as much as needed by the interlocutor. For example, the conversation between schizophrenic patients (PS) in this study and their younger siblings who were at a place to eat.

PS : Sendok garpu emas bagus untuk makan.

Adik : : Abang mau makan apa? Pilih lah!

PS : Sendok garpu emas bagus.

Adik : Iya, abang mau makan apa?

PS : Sendok garpu emas bagus ya.

PS : Gold cutlery is good for eating. (Looks at the spoon and fork in awe)

Brother : What do you want to eat? Choose it!

PS : Gold cutlery is good. (Still with the same look)

Brother : Yes, what do you want to eat?

PS : The golden cutlery is good, isn't it. (Still with the same look)

Based on the implication data from the conversation above, the sufferer does not focus on responding and reacting to his sister's stimulation. This is because, psychologically the patient at that time was in a manic phase. Manic phase in the medical world is identified as a phase in which a person is in a state of being too excited, interested, or excited to the point of not being able to control his emotions. In the example above, it can be seen that between the patient and his sister in the context of the articulator and the auditor, there is an unrelated and discontinuous process due to uncooperative 
sentence or utterance variables. The actions and reactions of sufferers who often repeat the words spoon, fork, gold, and good show that in interacting and communicating in this context, the patient has not been able to properly and reasonably accept the speech process of the speech partner so that it can be ascertained that the sufferer makes maxim deviations because in every speech each conversation participants do not contribute the information needed and instead provide information that is not needed.

Another example also appears in the following conversation between a person with schizophrenia and a nurse:

$\begin{array}{ll}\text { Perawat } & \text { : Kenapa bang Boy belum tidur? } \\ \text { PS } & \text { : Ayo main buku di luar! } \\ \text { Perawat } & \text { : Boy mau baca buku? Di kamar sini aja ya. } \\ \text { PS } & \text { : Ayo main buku di luar! } \\ \text { Perawat } & \text { : Bang Boy, ini udah malam. Kita baca buku di kamar saja dulu ya. } \\ \text { PS } & : \text {..... } \\ \text { Nurse } & : \text { Why isn't the boy sleeping yet? } \\ \text { PS } & \text { : Let's play a book outside! } \\ \text { Nurse } & : \text { Boy want to read a book? In this room, okay? } \\ \text { PS } & \text { : Let's play a book outside! (With loud volume and pressure) } \\ \text { Nurse } & : \text { Bang Boy, it's already late. Let's just read a book in our room, okay? } \\ \text { PS } & \text { :..... (Screaming loudly without clear words/phrases/sentences) }\end{array}$

In the case above, the context of the data is when the patient invites to read/play with a book outside the room. But the nurse refused because it was night and not allowed to do activities outside the room at that time. This makes the patient's psychological condition unstable, which in turn makes the patient assume that the nurse violates the maxim of quantity so that she does not grant the patient's request. The existence of elements that cannot be explained easily causes things that are obvious and do not need to be explained again are the speech implications of people with schizophrenia. These elements are deviations from the principle of cooperation.

In the reality of daily communication activities, the implementation of maxims can be divided into two, namely violating the maxims or obeying the maxims. The activity of violating the maxims is included in the maxim deviation as has been done by schizophrenic patients unconsciously. These activities can be divided into two, namely violating the maxims or making floats. 
As previously explained, the maxim of quantity requires that each participant of the utterance contribute enough and as much as needed by the interlocutor. If, it turns out that it is not in accordance with the intent and purpose of the maxim, then there has been a violation of the maxim of quantity.

\section{Quality Maxim}

With the maxim of quality, a speech participant is expected to convey something real and according to the actual facts in speaking. That fact must be supported and based on clear evidence. The following statements can be considered to clarify this statement.

$\begin{array}{ll}\text { Perawat } & \text { : 'Sekarang ini hari apa ya?' } \\ \text { PS } & \text { : 'Minggu, lihat saja di kalender kayak tidak bisa membaca saja' } \\ \text { Perawat } & \text { : 'Iya, sekarang hari Minggu. Kamu pintar.' } \\ \text { PS } & \text { : 'Iya dong, aku kan pintar' } \\ \text { Perawat } & : \text { Memang siapa yang ajari? } \\ \text { PS } & : \text { Ya suster dong. }\end{array}$

Nurse : 'What day is it today?'

PS : 'Sunday, just look at the calendar like you can't even read' (snort tone)

Nurse : 'Yes, it's Sunday. You are smart.' (trying to compliment the sufferer so that the sufferer doesn't feel neglected)

PS : 'Yes of course I am smart'

Nurse : Who is teaching?

PS : Yes, of course you. (Smiles while hugging the nurse)

Data that is recorded when the nurse wants to ask the name of the patient's day. With the maxim of quality, the sufferer as a speech participant is expected to be able to convey something real and according to the actual facts (that it is the nurse who teaches about the calendar) in speaking. That fact must be supported and based on clear evidence. The fact that in general the psycholinguistic symptom of people who do not concentrate is by speaking non-neutrally, then the mother who asks something (in this context is the name of the day) is considered as a trigger for impolite speeches or misunderstandings.

Based on the data above, we can get that the psychological condition of the sufferer's language has improved from the examples above. This is because the maxim that is obeyed is the maxim of quality. Conversational maxim which requires the participants to tell the truth and their contribution is based on sufficient evidence. 
The data above is data whose indexal information is carried out by nurses on patients when sufferers feel lonely and sad. The nurse performs her role by offering several rhetorical questions for the patient, that by stating the truth, the patient feels comfortable and does not feel left alone because the lonely phase of schizophrenia can cause the patient's language to deteriorate by speaking to himself or screaming himself and disappears. with hallucinations.

\section{Maxim of Relevance}

In the maxim of relevance, it is stated that in order to establish good cooperation between the speaker and the speech partner, each should be able to make a relevant contribution about something that is being spoken. Speaking without making such a contribution is considered not to comply and violates the principle of cooperation.

Perawat : 'Kalau tidak capek, nanti menyapu kamar ya nak'

PS : : 'Yang menyapu kamar jangan aku dong'

Perawat : 'Iho jadi siapa dong?'

PS : 'Yang nganggur saja'

Nurse $\quad$ : 'If you're not tired, then you'll sweep the room ok son'

PS : 'It's not me who sweeps the room'

Nurse : Then who?'

PS : 'let anyone unemployed'

Based on the conversation above, we can see that the word situation that occurs is that the nurse asks the schizophrenic patient to sweep his room with the aim of (conversational implicatures)

a. The patient does activities other than sleeping,

b. There will be guests present,

c. Assigning housework responsibilities to the patient. sufferer.

However, the reality is that the patient does not receive information in the conversational implicatures that occur, resulting in a discontinuity of conversation between the father and the patient as their child. That's because, in the conversation above, the maxim of relevance is violated. If a justification or correction is made, the maxim should look at the existing reality that the sufferer cannot be ordered or ordered with such speech.

In communicating, the speaker and the speech partner must maintain the cooperative principle of cooperation so that the communication process runs smoothly. Without the principle of cooperation, communication will be disrupted. This principle of cooperation is realized in various 
conversational rules. In more detail, Grice describes the principle of cooperation into four conversational maxims. In the conversation below, the maxim that fits Grice's theory is the maxim of relevance.

\section{Execution Maxim}

This implementation maxim requires the participants to speak directly, clearly, and not vaguely. People who speak without considering these things can be said to violate the Grice Cooperation Principle because they do not comply with the maxim of implementation.

PS : "Kenapa aku gak boleh buang sampah di lemari?

Perawat : 'Nanti lemarinya kotor'

PS : "Why can't I throw trash in the closet?

Nurse : 'the closet will dirty then'

From the above, we can see that people with schizophrenia can also have a conversation with the maxim of implementation. The nurse in the dialogue above conveys the information very clearly.

\section{Receptive Ability}

Receptive ability is the ability to accept in this study is the listening process that produces answers in the form of several utterances from the informant. Here are some examples of related cases.

"mau wulang ke humah kan" (mau pulang ke rumah kan)

do you want to go home?

In the speech above, there are phoneme errors that occur in several words such as the word wulang which is meant to be the word pulang, the phoneme /p/turns into a phoneme /w/ resulting in a word that has no meaning in Indonesian. Likewise, the word humah that the informant wanted to say was the word rumah, the change occurred from the phoneme $/ \mathrm{r} /$ to the phoneme $/ \mathrm{h} /$, the word humah itself has no meaning in Indonesian. So, actually what the informant wanted to say was to go home far away, even in irregular sentence patterns because what was meant was to want to go home far away.

“kasih kura yang makan” (kasih kera yang makan)

feed the monkey to eat

In the above utterance there is an error in the phoneme /e/ to /u/ contained in the word kura, the meaning of the word referred to by the informant is monkey. This phoneme error causes confusion in 
the meaning that is intended to be conveyed at first. Is turtle, kura or monkey the real word you want to convey, because each of these words has its own meaning, as below:

a. Ku.ra $n=$ spleen.

b. Kura-kura $\mathrm{n}=$ creeping animal with four legs, hard skin on the back, living in water and on land; Testudinata; 2 something shaped like a turtle (back); 3 lock key masters: fragile (KBBI V in network)

c. Kera $\mathrm{n}=$ the nature of mammals (which is classified as the most perfect), shaped like humans, hairy all over the body, has a brain that is relatively larger and smarter than other animals, including forage animals, seeds, etc. (KBBI V in network)

From this analysis, we can see that the informant mispronounced the phoneme in the word kera (monkey).

"nama na gunung merapi yang sangkuriang itu ya, ayo halan sana ya" (nama gunungnya gunung Merapi yang sankuriang itu ya. ayo jalan sana ya)

The name of the mountain is Mount Merapi, which is Sankuriang. Let's go there

In the speech above, there is a disturbance in the disclosure of a place that is intended but is not in the position of the place it should be. In what the informant said he wanted to take a trip to Mount Merapi, the location of the mountain is in the province of Central Java, but what the informant meant was not the mountain because if you look at the next utterance, it is Sangkuriang, the word is a symbol that is identical to a mountain which is located there. in West Java, namely Mount Tangkuban Parahu, so that what the informant meant was Mount Tangkuban Parahu not Mount Merapi, only that the informant had knowledge that the mountain was also a volcano.

"Rumahnya di manah? rumahnya rumah siapah? Rumahnya siapah? Rumah kamu siapah? Rumah si-rumah rumah siapah? Di mana rumahmu?"

"Where's the house? whose house? whose house? Who's your house? Whose house? Where is your house?"

In the utterance above, the informant repeats with the aim of improving his utterance. The informant corrected his speech because after the word home, the next word he said had an error because the word after it did not match what was asked. The word house is a class of nouns or nouns. The difference is, the informant does not repeat synonymous words, but repeats the same word nine times until the utterance matches what he wants to say, the word that is repeated is the word house in the utterance (1) where is his house? (2) his house (3) whose house? (4) whose house? (5) whose house is yours? (6) the house of the (7) house (8) whose house? (9) where is your house. 
In terms of sentence patterns, the arrangement produced by the informant is not in accordance with the rules of the Indonesian language. As the saying of your house, who is it? Should you want to make it as a question sentence, where is your house? and who are you? Who's not your house? This creates ambiguity in a question. Then in every utterance that ends in the phoneme /a/, the informant often adds the phoneme sound $/ \mathrm{h} /$ at the end of the word as follows. The sound of where becomes where, the sound of who becomes who.

"pilih hhhmmm karena ituh hhhmm apah marah hhmmmkarena apah ingung apah"

"choose hhhmmm because of that hhhmm are you angry hhmmm because what are you confused about"

In the statement above, the informant did not say it completely so that it became a sentence. As in the language disorder in the previous case, even in the speech above, the informant experienced a long pause with the sound /hhhmm/. The pause occurred long enough as the informant's thought process. During the break, the informant forgot the reason he had to give so he needed time to think or make up a reasonable reason. However, it turned out that the informant repeated the word because what was followed by the word which experienced lengthening and the addition of the consonant phoneme $/ \mathrm{h} /$ at the end of the word. This word was used by the informant as a filler because he still had not found the right reason and because he had already said so that he needed time to think. However, after repeating what the word is, the informant does not issue an utterance stating the reason to complete the utterance, but the informant instead adds a conjunction but to continue his unfinished utterance and remains unfinished because he did not give the final intonation ending a sentence, then thus the informant did not finish his utterance in the sentence.

\section{CONCLUSION}

Patients who have mental disorders (schizophrenic), are able to take advantage of the stages of language production such as conceptualization, formulation, articulation, and self-monitoring even though they are inconsistent. In addition, the schizophrenic language is understood based on units of language understanding, such as phonetics and phonology, morphology, syntax, and inconsistent text throughout the entire conversation. People with schizophrenia can carry out the language production process and understand language well for the communication process on condition that they comply with the principles of cooperation according to the four maxims set by Grice, namely the maxim of quantity, maxim of quality, maxim of relevance, and maxim of manner or implementation.

In the relapse phase, people with schizophrenia often violate the maxims and most of the maxims that are violated are the maxims of relevance. The maxim of relevance in its meaning is a 
maxim that requires the speech participants to understand each other. In addition, in the psycholinguistic context in the semi-quiet phase, people with schizophrenia are able to speak well. Although, sometimes the results of the process of language skills cannot be in harmony with the existing maxims of relevance.

In the process of receptive ability, namely listening, the informant responded with considerable difficulty due to unstable grasping power and concentration on the informant's psyche. In addition, the resulting utterances tend to be arbitrary and not in accordance with the way the utterance was intended to be conveyed, there were some language disturbances in the speaking practice process when expressing answers, such as (1) incorrect use of phonemes that caused differences in meaning and meaning as in the word shake that turns into a pan. These things lead to ambiguity and misunderstanding in the speaking process, (2) errors in the use of prepositions and conjunctions, tend to place the two categories of words stored arbitrarily by the informants.

Another thing that was noted was, in communicating, people with schizophrenia have a tendency to use words that they like so that their language style is unique to them. In choosing and using certain lexical, syntactic, and semantic elements, a person implies his personal affection and value in the words and sentences he makes. This means that each person projects his personality on his style of language. A person with schizophrenia can talk constantly. The chatter is only a repetition of the original verbal bulk with the addition of little by little or minus a few sentences. Initially this schizophrenic isolated his mind. Not much communication with the outside world, but a lot of dialogue with yourself.

Based on the conclusions of this study, it is recommended to immediately construct a rehabilitation therapy according to the problems experienced by Schizophrenia sufferers due to neurotransmitter distortion. This needs to be done and implemented early on to anticipate further damage caused by the continuity of neurotransmitter distortion, which can even spread and cause wider damage to the nervous system of the Schizophrenia sufferer.

\section{REFERENCES}

Alwasilah, A. C. (2005). Introduction to Applied Linguistic Research. Jakarta: Pusat Bahasa.

Azizah, N.R. (2013). Verbal Language Skills of Schizophrenic Patients: A Case Study. http://repository.unair.ac.id/27284/

Brown, Gillian and George Yule. (1996). Discourse Analysis. Jakarta: Gramedia Pustaka Utama.

Chaer, A. (2003). Psycholinguistics: Theoretical Studies. Jakarta: PT Rineka Cipta. 
Dardjowidjodjo, S. (1997). Echa: Indonesian Children's Language Development: Twelve- TwentyFour Months. Linguistics Meeting of the Atma Jaya Language Institute: Tenth (pp. 1-33). Yogyakarta: Canisius Publisher.

Dardjowidjojo, S. (2003). Psycholinguistics Understanding Human Language. Jakarta: Indonesia Torch Foundation.

Djajasudarma, T. F. (2010). Linguistic Methods: Research and Study Methods. Bandung: PT Refika Aditama.

Feminasari, I. (2005). The Meaning of Language by People with Schizophrenia: A Case Study at the Menur Mental Hospital in Surabaya. Malang: State University of Malang.

Garman, M. (1996). Psycholinguistics. Great Britain: Cambridge University Press.

Hawari. D. (2012), Holistic Approach to Schizophrenic Mental Disorder, Jakarta, FKUI.

Ikawati, Z. (2014). Pharmacotherapy of Central Nervous System Diseases. Yogyakarta: Science Exchange.

Kweldju, S. (1997). Development of Early Functional Dimensions of Children's Writing Discourse: A Case Study. Linguistics Meeting of the Atma Jaya Language Institute: Tenth (pp. 38-69). Yogyakarta: Canisius Publisher.

Levinson, Stephen C. (1983). Pragmatics. London: Cambridge University Press.

Maramis, W. F. (1980). Psychiatric Records. Surabaya: Airlangga University Press.

Muhadjir, N. (2000). Qualitative Research Methodology. Yogyakarta: Rake Sarasin. Mukti, M. G. (1993). Development of Indonesian Speaking Ability. Jakarta: Erlangga Publisher.

Pateda, M. (1990). Psycholinguistic Aspects. Flores-NTT: Nusa Indah.

Rahardjo, M. (2010, May 07). Mudia Rahardjo. Excerpted November 06, 2012, from Mudjia Rahardjo UIN Malang Web site: http://mudjiarahardjo.uin- malang.ac.id/material-siswa/203mengenal-dalam-dalam-about-case-study.html

Siregar, Iskandarsyah. (2020). Exploration and Implementation of the Cultural System as a Solution to National and State Problems. http://repository.unas.ac.id/id/eprint/811

Siregar, Iskandarsyah. (2021). Analysis of Betawi Language Interference on the Morphology of Adolescent Speech in Jakarta. Journal of Humanities and Social Sciences Studies, 3(8), 54-60. http://doi.org/10.32996/jhsss.2021.3.8.7 
Subyakto-Nababan, S. U. (1992). Psycholinguistics: An Introduction. Jakarta: Gramedia Pustaka Utama.

Suryani, Y. (2015). Deficit of Speech Pragmatics of Schizophrenic Patients at Menur Mental Hospital Surabaya: A Study of Clinical Pragmatics. Journal of Pena Indonesia, Volume 1, No.2

Syafyahya, L. (1993). Verbal Language Ability in Children with Schizophrenia. Padang: University of Andalas.

Tarigan, H. G. (1986). Psycholinguistics. Bandung: Angkasa Publisher.

Yule, George. (1996). Pragmatics. New York: Oxford University Press.

Yuliana, L. (2013). An Overview of Nurses' Knowledge About Patient Discharge Planning at Santo Borromeus Hospital, Bandung. Essay. Saint Borromeus College of Health, Padalarang. 
VERBAL COMMUNICATION OF SCHIZOPHRENIC PATIENTS DUE TO NEUROTRANSMITTER ... Iskandarsyah Siregar 